\title{
O Grande-Eixo de 'Humanidades e Ciências Sociais' numa graduação em odontologia: operacionalizando as Diretrizes Curriculares Nacionais
}

\author{
Leonardo Carnut
}

\section{Resumo}

Com a magnitude tomada pelo Sistema Único de Saúde (SUS), a reconfiguração das competências e habilidades do cirurgião-dentista tornou-se inadiável. A Estratégia de Saúde da Família consolidou-se como uma vasta rede com postos de trabalho para cirurgiões-dentistas cujo aumento foi expressivo nos últimos 16 anos. Aliado a isso, as Diretrizes Curriculares Nacionais (DCN) reforçam o investimento que as graduações devem fazer para formar o perfil (generalista e humanista) adequados para assunção desses espaços. Logo, este trabalho visou a organização curricular dos componentes curriculares do Grande-Eixo 'Humanidades e Ciências Sociais' do curso de graduação em odontologia da Universidade de Pernambuco (UPE) - Campus Arcoverde. Para elaboração deste desenho curricular, utilizou-se o método de validação de conteúdo onde, depois de se discutir entre 8 especialistas de diferentes áreas da Odontologia, qual o perfil desejado de profissional generalista a ser desenvolvido pelo curso, identificou-se que deve ser aquele que radicalmente expresse o que se preconiza nas DCNs. Assim, os conteúdos foram eleitos conformando-se um rol de componentes curriculares articulados entre si estruturados por eixos. Após a discussão, chegou-se ao consenso de que o objeto do Grande-Eixo 'Humanidades e Ciências Sociais' seriam os conhecimentos das ciências sociais, humanas e da filosofia indispensáveis para a reflexão sobre a constituição da saúde humana, sobre o compromisso da categoria com a mudança de paradigma, assim como a construção do conhecimento científico que englobe outros saberes. Assim, teve-se como objetivo principal garantir a formação humanística robusta necessária para a alcançar as habilidade e competências do compromisso social e da transformação da realidade social no qual o cirurgião-dentista deve deter. Este foi composto por 4 micro-eixos menores que os dá substância: a) Eixo 'Saúde Humana': objetiva descrever, instrumentalizar, analisar e interpretar a saúde como fenômeno social, a (re)organização dos serviços e sistema de saúde para acomodar esse novo paradigma de produção social da saúde e suas repercussões e inserção do cirurgião-dentista e das ações de saúde bucal; b) Eixo 'Compromisso Social': objetiva analisar, refletir, empoderar e, acima de tudo, agir sobre uma realidade social estabelecida para fins de mudança da prática odontológica, transitando-a de uma perspectiva biomédica para uma prática odontológica ética, pública, humanizada, politizada e baseada na responsabilidade comunitária; c) Eixo 'Conhecimento': objetiva munir, instrumentalizar, refletir e orientar o futuro cirurgião-dentista na descoberta dos tipos de conhecimentos e sua produção assim como o adequado uso das evidências do conhecimento científico em articulação com outros sabres para fins de produzir academicamente os diversos tipos de produtos intelectuais, incluindo nesses, o trabalho de conclusão de curso, e d) Eixo 'Mundo do Trabalho': objetiva orientar o futuro cirurgião-dentista para compreender as possibilidades de inserção no mundo do trabalho, assim como esclarecer suas escolhas e ajudar no "trilhar" de suas trajetórias profissionais. A produção destes 4 micro-eixos ajudou a contemplar a expectativa do grupo de experts e gerou a construção de um eixo longitudinal ao curso que fomenta o uso dos conhecimentos humanísticos e sociais para a construção de uma prática odontológica comunitária e socialmente engajada.

Descritores: Educação Odontológica; Educação Superior; Humanidades 